\title{
The Application of Behavioral Counseling with Positive Techniques Reinforcement to Improve Self-Confidence
}

\author{
Penerapan Konseling Behavioral dengan Teknik Positive Reinforcement untuk meningkatkan \\ Percaya Diri Siswa
}

\author{
Putri Majiatulhibah $^{1}$, I Wayan Tirka ${ }^{2}$, Dewi Arum. MWP ${ }^{3}$ \\ ${ }^{123}$ Universitas Pendidikan Ganesha \\ e-mail: putrimajiatulhibah58@gmai.com
}

\author{
Received July 04, 2017 \\ Revised August 17, 2017 \\ Accepted October 25, 2017 \\ Published Online December 30, \\ 2017
}

\section{Conflict of Interest \\ Disclosures: \\ The authors declare that they have no significant competing financial, professional or personal interests that might have influenced the performance or presentation of the work described in this manuscript.}

\begin{abstract}
This study was purposed to determine the effectivity of behavioral counseling by positive reinforcement technique to improved self confidence students of eleventh grade class AK C at SMK Negeri 1 Singaraja. One group pretest-posttest designed was used. The sample of this study were eight students which were grouped with purposive sampling. Student's self confidence were measured by questionnaire. Data were collected then analyzed by descriptive statistics and t-test. The results showed that behavioral counseling with positive reinforcement technique is effective to improved students self confidence, it seen from the analysis output ttest $>$ ttable with significance value $5 \%(\mathrm{v})$, it showed that students self confidence were improved. It can be concluded that alternative hipothesis of this study is accepted.
\end{abstract}

Keywords: behavioral counseling, positive reinforcement, self confidence

\begin{abstract}
Abstrak: Penelitian ini bertujuan untuk mengetahui efektivitas konseling behavioral dengan teknik positive reinforcement untuk meningkatkan percaya diri pada siswa kelas XI AK C SMK Negeri 1 Singaraja. Desain penelitian yang digunakan ialah one group pretest-posttest design. Pengambilan sampel menggunakan teknik purposive sampling dan diperoleh delapan orang sampel. Percaya dirisiswa diukur dengan kuesioner. Data yang diperoleh dianalisis dengan statistik deskriptif dan uji t. Berdasarkan hasil analisis, ditemukan bahwa konseling behavioral dengan teknik positive reinforcement untuk meningkatkan percaya diri siswa, ini dilihat dari hasil analisis nilai thitung $>$ ttabel dengan taraf signifikan 5\% (12.831>1.895), berarti terjadi peningkatan percaya diri pada siswa. Dapat disimpulkan bahwa hipotesis alternative yang diajukan dalam penelitian ini dapat diterima.
\end{abstract}

Kata Kunci: konseling behavioral, teknik positive reinforcement, percaya diri

How to Cite: Majiatulhibah, P., Tirka, I. W., \& MWP, D. A. (2017). The Application of Behavioral Counseling with Positive Techniques Reinforcement to Improve Self-Confidence. Bisma, 1(2), 86-96. https://doi.org/10.23887/128192017 


\section{Pendahuluan}

Pendidikan merupakan salah satu alat ukur kemajuan sumber daya manusia suatu negara maka, pemerintah selalu berusaha untuk meningkatkan prestasi belajar peserta didik, hal ini dilakukan dengan berbagai upaya diantaranya menyediakan sarana pembelajaran, meningkatkan kualiatas tenaga pengajar, pengembangan kurikulum serta menciptakan lingkungan belajar yang nyaman sehingga dapat mengembangkan potensi-potensi yang dimiliki oleh siswa, sehingga tujuan pendidikan dapat tercapai. Sekolah merupakan suatu lingkungan yang didalamnya terdapat berbagai macam individu yang memiliki karakter yang berbeda-beda. Siswa sebagai individu memiliki beberapa karakteristik yang perlu dipahami, diantaranya siswa memiliki keunikan yang berbeda-beda dan dia selalu berada dalam proses perkembangan yang bersifat dinamis. Keunikan itu dikarenakan tiap individu memiliki sejumlah potensi, kecakapan, kekuatan, motivasi, minat, kebiasaan, persepsi, serta karakteristik fisik dan psikis yang berbedabeda karena individu hidup dilingkungan dan latar belakang yang berbeda-beda. Keragaman kemampuan dan karakteristik tersebut terintregasi membentuk tipe atau pola sendiri-sendiri, yang berbeda antara seorang individu dengan individu yang lainnya dan nantinya berimbas pada perilaku yang ditampilkan.

Sekolah sebagai lembaga formal berperan dalam memberi pengetahuan dan keterampilan melalui berbagai kegiatan, baik dalam bidang akademik maupun non akademik. Seluruh aktivitas yang dilakukan disekolah pada dasarnya guna memberikan kesempatan kepada siswa untuk mengaktualisasikan dirinya secara optimal. Dalam penyelenggaraan pendidikan di sekolah terdapat berbagai aktivitas belajar yang harus dilaksanakan oleh siswa, seperti mengerjakan tugas dengan baik, memperhatikan penjelasan guru, mengeluarkan pendapat, dan berbagai aktivitas lainnya. Keberhasilan menjalani aktivitas-aktivitas tersebut tidak sematamata ditentukan oleh kecerdasan intelektual tetapi juga oleh keyakinan dan kesadaran akan tanggung jawab yang kuat. Suatu kenyataan yang tidak dapat dielakan bahwa dalam proses pembelajaran sering timbul berbagai masalah pada diri siswa, misalnya saja kurangnya keaktifan siswa saat mengikuti pelajaran. Sehingga menjadikan proses pembelajaran tak ubahnya sebagai tempat penyampaian informasi, dimana guru lebih aktif sedangkan siswa pasif. Seluruh siswa mendambakan sukses dalam belajar, untuk mencapai keberhasilan dalam belajar maka kunci pertama yang harus dimiliki adalah rasa percaya diri, karena rasa percaya diri yang baik akan merangsang timbulnya dorongan untuk berprestasi dalam belajar. Rasa percaya diri akan membawa pengaruh yang besar dalam pergaulan dilingkungan sekolah maupun dalam hal prestasi belajar anak disekolah. Memiliki rasa percaya diri yang tinggi sangat penting. Rasa percaya diri identik dengan kekuatan pribadi.

Untuk mempertebal rasa percaya diri, kita harus mampu untuk melawan kecendrungan internal yang menawarkan godaan untuk menyimpang yang dapat memperlemah personal power yang berarti dapat memperlemah rasa percaya diri. Dengan percaya diri banyak manfaat yang akan kita peroleh dan tentunya sangat berguna untuk diri kita sendiri.Insyirahman (2005:1) menyimpulkan bahwa manfaat yang bisa diperoleh apabila mempunyai rasa percaya diritinggi, yaitu : (a) Diri menilai bahwa kualitas pribadi muncul dari dalam, (b) Kuat dalam berargumen dan selalu ingin menang, (c) Mental bersaing sangat tinggi, (d) Tidak mudah menyerah, (e) Selalu ingin punya alternatif dalam menyelesaikan setiap masalah.

Maslow (dalam Agung dan Iswidharmanjaya, 2004:13) menyatakan, "Percaya diri merupakan modal dasar untuk pengembangan aktualisasi diri (eksplorasi segala kemampuan dalam diri." Dengan percaya diri seseorang akan mampu mengenal dan memahami diri sendiri. Sementara itu, kurang percaya diri dapat menghambat pengembangan potensi diri.

Jadi orang yang kurang percaya diri akan menjadi seseorang yang pesimis dalam menghadapi tantangan, takut dan ragu-ragu untuk menyampaikan gagasan, bimbingan dalam menentukan pilihan dan sering membanding-bandingkan dirinya dengan orang lain.

Dapat dikatakan bahwa orang percaya diri adalah orang yang mandiri, yaitu berdiri sendiri tanpa tergantung pada orang lain sepenuhnya. Kemandirian dalam pribadi percaya diri terbentuk karena yakin pada kemampuannya serta telah mengenal kekurangan dan kelebihan yang ada dalam dirinya (Agung dan Iswidharmanjaya, 2004:13).

Kepercayaan diri sendiri merupakan hal yang dapat menimbulkan rasa aman, karena hal itu juga berhubungan erat keamanan atau kemampuan menjaga tingkat atau kadar semosional atau sering disebut dengan emotional security, makin mantap kepercayaan diri makin mantap pula emotional security. Hal ini dapat terlihat pada sikap dan tingkah laku seseorang, tidak mudah bimbang, tidak mudah lemas, tenang dan tegas. Suhyanto (Junaidin, 2002:51).(Astuti \& Cahyadi, 2007; Bernabe, Chamoiseau, \& Confiant, 
1990; Bull, 1993; Felsenstein, 1985; Garbula, 2009; Kadek Suhardita, 2011; Pankiewicz, 2007; Papahana, Ke, Hopuna, \& Ka, 2014; Penar-zadarko \& Binkowska-bury, 2008; Siekań ska, 2004; Tibshirani, 1986; U.V.Duvel, n.d.; Warman, 2013)

Berdasarkan hasil pengamatan selama mengadakan kegiatan PPL di SMK Negeri 1 Singaraja, diketahui bahwa pada siswa kelas XI terdapat beberapa orang siswa yang menunjukkan rasa percaya diri yang rendah dalam belajar. Sikap-sikap yang mereka tunjukkan secara umum seperti, sikap mudah cemas ketika mereka ditunjuk guru untuk tampil di depan temanteman mereka, ketika disuruh bertanya siswa kebanyakan yang berdiam diri serta siswa kurang memperhatikan guru pada saat menerangkan dan biasanya kalau ditunjuk dengan paksa baru siswa mau untuk aktif, serta sering menyendiri, mudah putus asa apabila mereka mendapat nilai-nilai yang kurang, cenderung tergantung pada orang lain dalam mengerjakan tugas-tugas sekolah. Dari kenyataan yang telah peneliti diamati pada SMK Negeri 1 Singaraja, banyak ditemukan siswa yang memiliki potensi baik dengan intelegensi yang tinggi namun mereka tidak mencapai prestasi yang optimal di karenakan percaya diri nya rendah.

Melihat kenyataan tersebut tentunya kita berharap siswa mampu memiliki rasa percaya diri yang baik dan tidak menjadikan siswa berkembang menjadi tidak yakin akan kemampuan yang dimilikinya. Untuk mengatasai rasa percaya diri yang rendah tersebut, sekolah dalam hal ini telah melakukan usaha-usaha yang bertujuan untuk membina anak, seperti menugaskan anak sebagai petugas upacara, membuat organisasi intra sekolah (OSIS), mengikutsertakan siswa dalam kegiatan porseni dan lain sebagainya. Akan tetapi tampaknya usaha-usaha tersebut tidak berhasil secara optimal karena masih ada beberapa anak yang menampakkan rasa peracaya diri yang rendah. Hal ini disebabkan karena siswa masih merasa canggung, tidak mampu memperbaiki keadaan diri.

Dengan adanya faktor tersebut, adapun solusi yang diambil yaitu peneliti mengadakan model konseling behavioral. Salah satu cara yang dapat digunakan untuk mengubah perilaku negative menjadi perilaku yang lebih positif yaitu dengan pendekatan konseling behavioral. Model konseling behavioral dipilih karena lebih menekankan mengubah perilaku kearah yang lebih baik melalui teknik-teknik yang diberikan nantinya. Jika menggunakan model konseling lainnya, belum tentu tepat karena peneliti lebih menekankan perubahan tingkah laku untuk siswa. Corey,

(2003:197) menyatakan bahwa behaviorisme adalah suatu pandanga ilmiah tentang tingkah laku manusia. Dalil dasarnya adalah tingkah laku itu tertib dan bahwa eksperimen yang dikendalikan dengan cermat akan menyingkapkan hokum-hukum yang mengendalikan tingkah laku. Menurut Bootzim (dalam Komalasari, dkk, 2011:154)

"konseling behavioral dikenal juga dengan modifikasi perilaku yang dapat di artikan sebagai tindakan yang bertujuan untuk mengubah perilaku". Modifikasi perilaku dapat pula diartikan sebagai usaha menerapkan perinsip-perisip belajar pada perilaku manusia. Menurut Wolpe, modifikasi perilaku adalah perinsip-perinsip belajar yang telah tertuju secara eksperimental untuk mengubah perilaku yang tidak adaptif. Kebiasaan-kebiasaan yang tidak adaptif dilemahkan dan dihilangkan, perilaku adptif ditimbulkan dan dikuhkuhkan (Komalasari, dkk, 2011:154).(Damayanti \& Aeni, 2016; Denison, O’Reilly, Schmid, Kennedy, \& Sweat, 2008; Foa, Rothbaum, Riggs, \& Murdock, 1991; Konseling et al., 2016; Siswa, Viii, Smp, Sawan, \& Pelajaran, 2013; Steptoe, Kerry, Rink, \& Hilton, 2001; Sutarjo, Wmp, \& Suarni, 2014; Whitlock, Orleans, Pender, \& Allan, 2002)

Model konseling behavioral dalam penelitian ini menggunakan teknik positive reinforcement (penguatan positif). Penguatan positif yaitu salah satu teknik yang dalam pembentukan tingkah laku dari teori konseling behavioral. Penguatan positif merupakan respon terhadap suatu tingkah laku yang dapat meningkatkan kemungkinan berulangnya kembali tingkah laku yang diharapkan. Dalam artian, penguatan positif adalah pembentukan suatu pola tingkah laku dengan memberikan ganjaran atau perkuatan segera setelah tingkah laku yang diharapkan muncul. Dengan memberikan penguatan positif, maka perilaku yang diinginkan itu akan ditingkatkan atau diteruskan. Penguatan positif bisa menjadi alat yang ampuh untuk membentuk tingkah laku yang diharapkan. Penguatan itu bisa berupa kata-kata verbal seperti bagus sekali, tepat sekali. Berupa kalimat verbal seperti saya suka hasil kerja anda, pertahankan dan ditingkatkan hasil kerja kamu. Lalu penguatan non-verbal berupa gerakan seperti ancungan jempol, memberikan senyuman, berupa tanda penghargaan dan hadiah-hadiah atau dengan mengkombinasikannya sehingga sikap yang diinginkan akan dibentuk dan sikap yang tidak baik akan sedikit demi sedikit dihilangkan. Skiner (dalam Corey, 2003:222), mengemukakan penguatan positif jauh lebih efektif dalam mengendalikan 
tingkah laku karena hasilhasilnya lebih bisa diramalkan serta kemungkinan timbulnya tingkah laku yang tidak diinginkan akan lebih kecil.(Abanto Alvarez, J; Pinto e Carvalho Rezende, K M; Bönecker, M; Nahás Pires Corrêa, F; Salete Nahás Pires Corrêa, 2010; Aydın, Fahjan, \& Çömlekçioğ lu, 2007; ÇUHADAR, 2005; Egas, 1966; Fallis, 2013; Inoue, 2006; López Mena, 1992; Maag, 2001; Mora, Salazar, \& Valverde, 2001; Na, Wa, Asili, \& Ofisi, 2008; Shapiro, Bloomsmith, \& Laule, 2003; Smidt, 1975; Vries, n.d.; Zegers \& Duits-nederlandse, 2008)

Positive reinforcement mempunyai banyak keunggulan untuk meningkatkan dan memelihara perilaku. Letak keunggulannya tidak hanya pada efektifitasnya, tetapi juga pada efek sampingnya. Subjek yang mendapat positive reinforcement cenderung menggeneralisasikan kepada dirinya, sehingga merasa dirinya berharga. Hubungan antara penerima dan pemberi pengutan pun menjadi baik, karena pemberi pengutannya diasosiasikan dengan sesuatu yang menyenangkan. Kaitannya dengan masalah yang diteliti bahwa dalam menumbuhkan percaya diri tidaklah mudah, ada beberapa faktor yang dapat menumbuhkan kepercayaan diri anak misalnya seperti pengalaman yang menyenangkan. Memberikan dukungan serta pengakuan merupakan pengalaman yang menyenangkan bagi anak sehingga anak merasa di hargai oleh lingkungannya. Bentuk pengakuan dan penghargaan diri yang positif dituangkan melalui teknik positive reinforcement sehingga akan menjadi motivasi langsung bagi anak untuk mengembangkan kepercayaan dirinya. Adapun hipotesis alternatif yang diajukan berbunyi, "Konseling behavioral dengan teknik positive reinforcement efektif untuk meningkatkan percaya diri siswa kelas XI AK C di SMK Negeri 1 Singaraja."

\section{Metode}

Penelitian ini tergolong penelitian "praeksperimental" terhadap percaya diri siswa kelas X AK C SMK Negeri 1 Singaraja. Adapun rancangan yang digunakan adalah One Group Pretest-Posttest Design. Populasi penelitian ini adalah seluruh siswa kelas XI AK C SMK Negeri 1 Singaraja pada tahun pelajaran 2017/2018 yang berjumlah 36 orang. Sampel di ambil menggunakan teknik purposive sampling, diperoleh delapan orangn sebagai sampel. Data pada penelitian ini dikumpulkan menggunakan kuesioner percaya diri yang terdiri dari 40 butir soal. Hasil analisis data pada uji coba instrument memberikan harga Alpha Cronbach sebesar 0.942, sesuai dengan kriteria yang telah ditentukan, reliabilitas masing-masing kuesioner rendah diriberada pada kategori sangat tinggi. Dengan demikian, kuesioner percaya diriyang diujicobakan memenuhi kriteria untuk digunakan dalam penelitian ini.

Analisis data yang digunakan meliputi teknik analisis deskriptif dan uji t. Teknik analisis deskriptif meliputi deskripsi persentase hasil pretest dan posttest, skor rata-rata (mean), skor gain ternormalisasi. Sedangkan uji t untuk menyelidiki pengaruh variabel bebas (konseling behavioral teknik shaping) terhadap variabel terikat (rendah diri) dan uji lanjut serta effect size.

Tabel 01. Data Pretest, Posttest dan Gain Score Sampel Penelitian

\begin{tabular}{lccccc}
\hline No & Sampel & \multicolumn{2}{c}{ Hasil Kuesioner } & $\begin{array}{c}\text { Selisih (Gain } \\
\text { Score) }\end{array}$ & GSn \\
\cline { 2 - 4 } & Percaya Diri & PreTest $\left(\boldsymbol{X}_{1}\right)$ & PostTest $\left(\boldsymbol{X}_{2}\right)$ & & \\
$\mathbf{1}$ & GB & 102 & 157 & 55 & 0.56 \\
$\mathbf{2}$ & IK & 72 & 168 & 96 & 0.75 \\
$\mathbf{3}$ & KA & 64 & 172 & 108 & 0.79 \\
$\mathbf{4}$ & KW & 95 & 160 & 65 & 0.62 \\
$\mathbf{5}$ & KAW & 66 & 175 & 109 & 0.81 \\
$\mathbf{6}$ & KG & 70 & 154 & 84 & 0.65 \\
$\mathbf{7}$ & LP & 73 & 163 & 90 & 0.71 \\
\hline
\end{tabular}




\begin{tabular}{rrcccc}
\hline $\mathbf{8}$ & NW & 69 & 153 & 84 & 0.64 \\
& Rata-Rata & 76.375 & 162.75 & 86.375 & 0.69173 \\
& Total & 611 & 1302 & 691 & 5.53 \\
\hline
\end{tabular}

\section{Results and Discussion}

Hasil penskoran yang diperoleh dari pengumpulan data-data mengenai tingkat percaya diri berdasarkan hasil kuesioner dari sampel yang disajikan pada tabel berikut ini. dari data dalam tabel di atas dapat dilihat bahwa terjadi peningkatan skor prestest ke posttest pada masing-masing sampel yang ditunjukkan oleh gain score-nya. Deksripsi masing-masing sampel divisualisasikan dalam grafik berikut.

Analisis data kuantitatif adalah analisis yang didasarkan pada nilai kuantitatif variabel bebas (konseling behavioral teknik positive reinforcement) terhadap variable terikat (percaya diri). secara statistic dengan correlated data/paired sampel t-test dimaksudkan untuk mengetahui efektifitas atau pengaruh dari variabel bebas terhadap variabel terikat dilihat dari perbedaan pretest dengan posttest. Hasil analisis data kuantitatif dengan program SPSS diperoleh keluaran (ouput).

Tabel 02. Paired Samples Statistic Pretest-Posttest

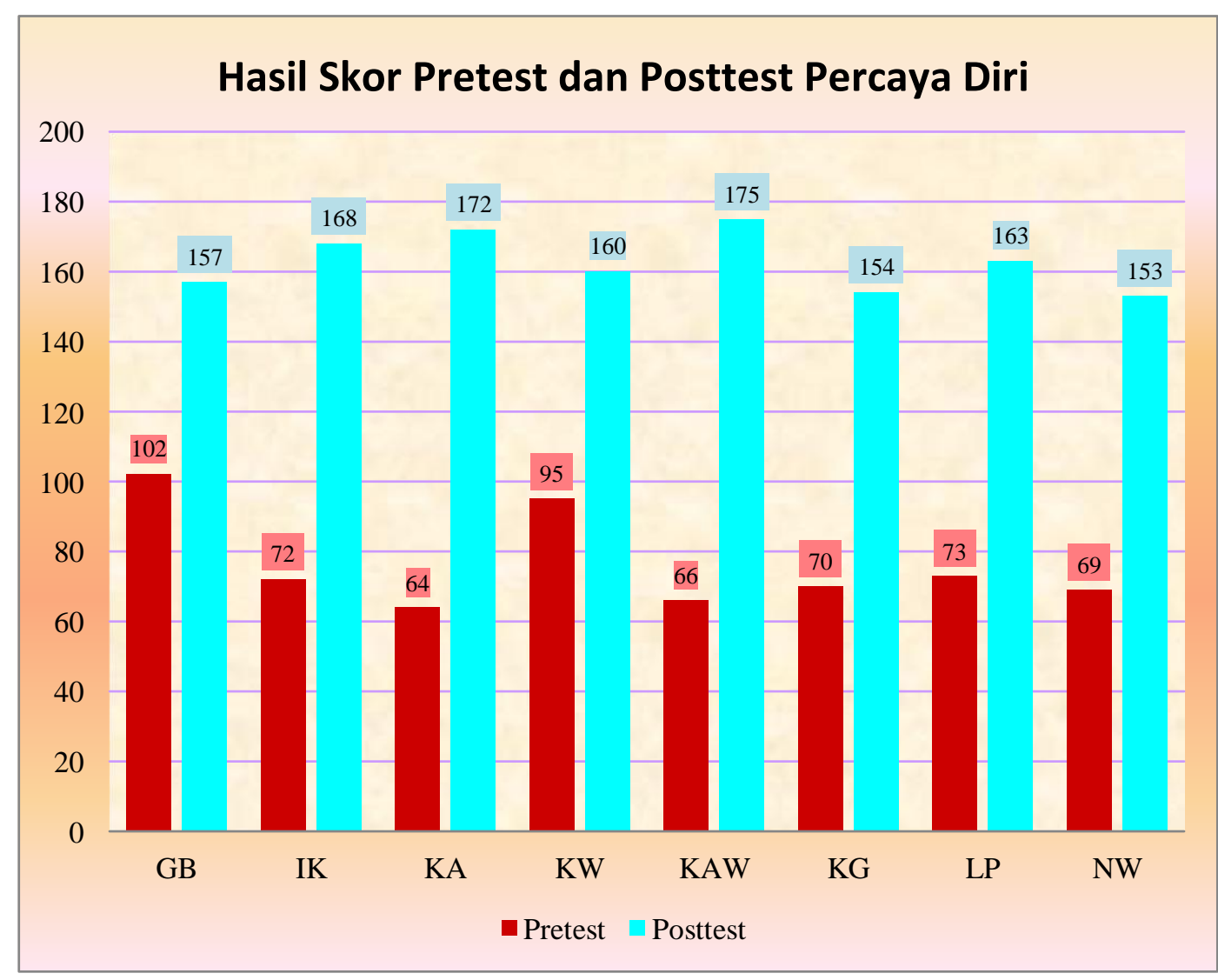

Grafik 01. Perbadingan Skor Pretest Dan Posttest 


\begin{tabular}{crrrr}
\hline & Mean & N & \multicolumn{1}{c}{ Std. Deviation } & \multicolumn{1}{c}{ Std. Error Mean } \\
\hline Pretest & 76.3750 & 8 & 14.09090 & 4.98189 \\
Posttest & $1.6275 \mathrm{E} 2$ & 8 & 8.24188 & 2.91394 \\
\hline
\end{tabular}

Tabel 03. Paired Samples Correlations Pretest-Posttest Paired Samples Correlations

\begin{tabular}{ccccr}
\hline & N & Correlation & Sig. \\
\hline Pretest \& Posttest & 8 & .414 & .031 \\
\hline
\end{tabular}

Tabel 04. Paired Samples Test Pretest-Posttest Paired Samples Test

\begin{tabular}{ccccccccr}
\hline & & \multicolumn{3}{c}{ Paired Differences } & t & df & Sig. \\
(2tailed)
\end{tabular}

Output analisis SPSS menunjukkan bahwa rata-rata skor kuisioner percaya diri pada pretest 76.375 dan rata-rata skor kuesioner percaya diri pada posttest 162.75 . Ini menunjukkan terjadi peningkatan ratarata hasil kuesioner percaya diri. Oleh karena skor hasil kuisioner percaya diri pada posttest tinggi maka percaya diri siswa tersebut semakin tinggi. Dan ini menunjukkan terjadi peningkatan percaya diri pada sampel.

Berdasarkan nilai thitung pada output menunjukkan angka 12.831 ini berarti terjadi peningkatan percaya diri. Dengan $\mathrm{db}=\mathrm{n}-1$ diperoleh $\mathrm{db}=7$ pada taraf signifikan $5 \%$ maka didapatkan ttabel $=1.895$. Dari hasil korelasi antara pretest dengan posttest, menghasilkan angka korelasi 0.414 dengan nilai probalibilitas di bawah 0,05 (nilai signifikan output analisis 0.030 ). Hal ini menyatakan bahwa korelasi antara rata-rata pretest dengan rata-rata posttest percaya diri dan konseling behavioral dengan teknik percaya diri adalah kuat dan signifikan.

Menurut Hadi (2002: 149), jika nilai probabilitas < $\alpha$, maka H0 ditolak. Yang berarti $12.831<\alpha$, dengan demikian karena HO ditolak maka Ha diterima, dimana Ha berbunyi "Konseling behavioral dengan teknik positive reinforcement efektif untuk meningkatkan percaya diri siswa kelas XI AK C di SMK Negeri 1 Singaraja".

Untuk mengetahui tingkat keefektifan konseling behavioral teknik positive reinforcement dilakukan uji $t$ lanjut dengan uji t Burney. 

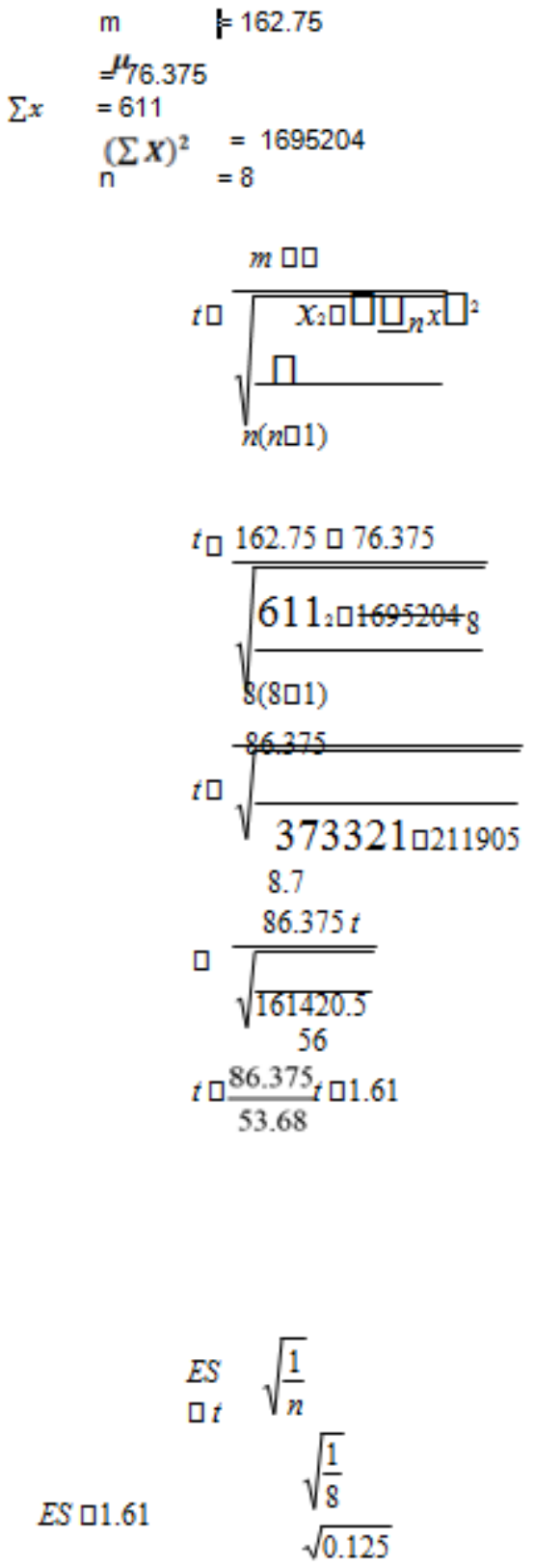

ES口1.61

\section{ES ㅁ1.61x0.353}

ES $\square 0.915$

Berdasarkan hasil penghitungan diatas maka konseling behavioral teknik positive reinforcement dinyatakan efektif untuk meningkatkan percaya diri dengan hasil effect size atau ES sebesar 0.915 yang berarti konseling behavioral teknik positive reinforcement memiliki efektivitas sebesar $91.5 \%$ dalam meningkatkan percaya diri.

Sesuai dengan tujuan penelitian yaitu untuk mengetahui efektivitas konseling behavioral dengan teknik positive reinforcement terhadap peningkatan percaya diri siswa, maka pengumpulan data yang dilakukan meliputi tes awal (pretest) dan tes akhir (posttest). Tes awal (pretest) dilakukan untuk mengetahui siswa yang memiliki rasa percaya diri rendah. Setelah itu diadakan perlakuan dimana perlakuan berupa konseling behavioral dengan teknik positive reinforcement. 
Gejala awal yang ditunjukkan siswa yang memiliki rasa percaya diri rendah yaitu menunjukkan rasa takut, malu, kebiasaan mencontek, kecemasan dalam menghadapi sesuatu yang berpengaruh terhadap emosi yang dimiliki siswa dan tidak bersemangat saat mengikuti pelajaran. Hal ini dapat dilihat dari perilaku siswa yang nampak pada kesehariannya dalam mengikuti kegiatan belajar di kelas seperti: jika diberikan kesempatan untuk bertanya terhadap materi yang dibahas mereka lebih banyak diam, siswa grogi ketika ditunjuk guru untuk menjawab pertanyaan, malu ketika tampil untuk berbicara, minder ketika diskusi kelompok karena merasa tidak ada ide yang bisa disumbangkan, mudah putus asa ketika pendapatnya kurang bisa diterima oleh teman-temannya. Suhyanto (dalam Junaidin 2002:51) berpendapat bahwa "kepercayaan diri sendiri merupakan hal yang dapat menumbulkan rasa aman, karena hal itu juga berhubungan erat keamanan atau kemampuan menjaga tingkat atau kadar emosional atau sering disebut dengan emotional security, makin mantan kepercayaan diri makin mantap pula emotional security. Hal ini dapat terlihat pada sikap dan tingkah laku seseorang, tidak mudah bimbang,tidak mudah lemas,tenang dan tegas. Dalam proses konseling kelompok behavioral dengan teknik positive reinforcement menggunakan cara- cara interaktif, saling menukar gagasan dan pengalaman antara sesama anggota kelompok untuk membahas masalah bersama. Sehingga dalam konseling kelompok ini siswa betul-betul mau dengan segala kemampuan dan kreatifitasnya untuk tampil sebagai sosok yang penuh rasa percaya diri yang tinggi sehingga siswa mampu mengembangkan potensi diri, kepribadian, kasih sayang, sosialisasi yang berguna, antara lain berani berbicara di muka umum, berani mengeluarkan pendapat, berani menanggapi pendapat orang lain, mampu bertenggang rasa dan dapat mengembangkan bakat dan minatnya.

Peneliti mengajukan satu hipotesis alternatif yang berbunyi, "Konseling behavioral dengan teknik positive reinforcement efektif untuk meningkatkan percaya diri siswa kelas XI AK C di SMK Negeri 1 Singaraja", yang berdasarkan hasil penelitian ternyata hipotesis ini diterima.

Konseling behavioral dengan teknik positive reinforcement efektif untuk meningkatkan percaya diri siswa kelas XI AK C di SMK Negeri 1 Singaraja, ini mungkin disebabkan karena: (1) Teknik positive reinforcement dapat mengubah perilaku siswa yang memiliki kepercayaan diri rendah menjadi lebih percaya diri melalui dukungan, pengakuan dan penghargaan diri yang positif, sehingga siswa mampu mendapatkan hasil belajar yang optimal. (2) Positive reinforcement mempunyai banyak keunggulan untuk meningkatkan dan memelihara perilaku. Letak keunggulannya tidak hanya terletak pada pengaruhnya, tetapi juga pada efek sampingnya. Subjek yang mendapat positive reinforcement cenderung menggeneralisasikan kepada dirinya, sehingga merasa dirinya berharga. Hubungan antara penerima dan pemberi penguatan pun menjadi baik, karena pemberi penguatannya diasosiasikan dengan sesuatu yang menyenangkan.

Peningkatan terjadi berdasarkan analisis yang dilakukan ternyata hasil yang diperoleh mendukung teori yang mendasari penelitian ini yaitu secara teoritis dapat dikatakan bahwa konseling behavioral dengan teknik positive reinforcement efektif untuk meningkatkan rasa percaya diri pada siswa.

\section{Kesimpulan}

Berdasarkan hasil penelitian dan pembahasan pada BAB IV, maka dapat ditarik kesimpulan sebagai berikut.

Konseling behavioral dengan teknik positive reinforcement efektif untuk meningkatkan percaya diri siswa kelas XI AK C di SMK Negeri 1 Singaraja karena mampu membuat individu bisa belajar mempercayai dirinya sendiri, berpikir dan memutuskan untuk dirinya sendiri, dan mengungkapkan perasaanperasaannya sehingga mampu mengembangkan dirinya kearah yang positif seperti mampu mengembangkan percaya diri lebih baik lagi. Peningkatan percaya diri tersebut dapat diketahui dengan melihat hasil pretest dan posttest siswa, rata-rata skor kuisioner percaya diri pada pretest 76.375 dan ratarata skor kuesioner percaya diri pada posttest 162.75. Ini menunjukkan terjadi peningkatan rata-rata hasil kuesioner percaya diri pada sampel. 


\section{Referensi}

Asri, Ni Luh. (2014). Pengaruh Konseling Behavioral Dengan Teknik Positive Reinforcement untuk Meningkatkan Rasa Percaya Diri Dalam Belajar Pada Siswa Kelas VIII SMP Negeri 2 Singaraja Tahun Pelajaran 2013/2014. E-Journal (tidak diterbitkan). Singaraja: Jurusan Bimbingan Konseling, Fakultas Ilmu Pendidikan, UNDIKSHA.

Corey, Gerald. (2003). Teori dan Praktek Konseling Dan Psikoterapi. Bandung:PT Refika Aditama.

Hadi, Tri. (2002). Statistik Inferensial. Yogyakarta: Penerbit Andi.

Inyirahman, AlHakim. (2005). Mengatasi Rasa Tidak Percaya Diri. Jakarta:Puspa Swara.

Iswidharmanjaya, Derry dan Agung. (2004). Suatu Hari Menjadi Lebih Percaya Diri. Panduan Bagi Remaja Yang Masih Mencari Jati Dirinya. Jakarta : Gramedia.

Junaidin., Ghany. (2002). Menanamkan Rasa Percaya Diri pada Anak. Jakarta: Kencana Prenada Media Group.

Komalasari, dkk. (2011). Teori dan Teknik Konseling. Jakarta: PT. Indeks.

Abanto Alvarez, J; Pinto e Carvalho Rezende, K M; Bönecker, M; Nahás Pires Corrêa, F; Salete Nahás Pires Corrêa, M. (2010). Propuestas no-farmacológicas de manejo del comportamiento en niños. Revista Estomatológica Herediana, 20(2), 101-106. Retrieved from http://s3.amazonaws.com/academia.edu.documents/39846111/Propuestas_nofarmacologicas_de_manejo_del_comportamiento_en_ninos.pdf?AWSAccessKeyId=AKIAIWOWY YGZ2Y53UL3A\&Expires=1492272686\&Signature=2iXLwP462L2t6s2\%2FOIZo9rGsy4Y\%3D\&re sponse-content-disposition $=\mathrm{i}$

Astuti, S. W., \& Cahyadi, I. G. (2007). Pengaruh elemen ekuitas merek terhadap rasa percaya diri pelanggan di Surabaya atas keputusan pembelian sepeda motor Honda. Majalah Ekonomi, 17(2), 145156. Retrieved from http://e-journal.unair.ac.id/index.php/JEBA/article/download/4207/2847

Aydın, E. Ö., Fahjan, Y. M., \& Çömlekçioğlu, R. (2007). Deprem Bölgelerindeki Tarihi Kagir Yapıların Güçlendirilmesinde Kullanılan Yeni Teknikler. International Earthquake Symposium Kocaeli 2007, 636644. Retrieved from http://sismik-guclendirme.com/uploads/different/files/articles/636-644-Deprem Bolgelerindeki Tarihi Kagir Yapilarin Guclendirilmesinde Kullanilan YeniTeknikler.pd

Bernabe, J., Chamoiseau, P., \& Confiant, R. (1990). In Praise of Creoleness. Callaloo, 13(4), 886-909. https://doi.org/10.2307/2931390

Bull, D. M. H. J. J. (1993). hillis-bull-systematicBiology-1993.pdf. Retrieved from https://academic.oup.com/sysbio/article-abstract/42/2/182/1730933

ÇUHADAR, M. T. (2005). Türk KamYönetiminde PersonelGüçlendirme: Sorunlar Ve ÇözüÖnerileri. Erciyes Üniversitesi iiBF Dergisi, (25), 1-24. Retrieved from http://dergipark.ulakbim.gov.tr/erciyesiibd/article/download/5000115335/5000107336

Damayanti, R., \& Aeni, T. (2016). Rika Damayanti, Tri Aeni, 3(1), 1-10. Retrieved from http://ejournal.radenintan.ac.id/index.php/konseli/article/view/572

Denison, J. A., O’Reilly, K. R., Schmid, G. P., Kennedy, C. E., \& Sweat, M. D. (2008). HIV voluntary counseling and testing and behavioral risk reduction in developing countries: A meta-analysis, 19902005. AIDS and Behavior, 12(3), 363-373. https://doi.org/10.1007/s10461-007-9349-x

Egas, C. (1966). Vragen rond de jeugd van 1966. Socialisme En Democratie. Retrieved from http://pubnpp.eldoc.ub.rug.nl/FILES/root/tijdschrift/SenD/SenD023/SenD_1966_09.pdf 
Fallis, A. . (2013). The use of positive reinforcement training techniques to enhance the care, management, and welfare of primates in the laboratory. Journal of Chemical Information and Modeling, 53(9), 16891699. https://doi.org/10.1017/CBO9781107415324.004

Felsenstein, J. (1985). Felsenstein_Evolution_1985.pdf. Retrieved from http://onlinelibrary.wiley.com/doi/10.1111/j.1558-5646.1985.tb00420.x/full

Foa, E. B., Rothbaum, B. O., Riggs, D. S., \& Murdock, T. B. (1991). Treatment of posttraumatic stress disorder in rape victims: A comparison between cognitive-behavioral procedures and counseling. Journal of Consulting and Clinical Psychology, 59(5), 715-723. https://doi.org/10.1037/0022006X.59.5.715

Garbula, J. M. (2009). Dzieci wobec stereotypów płci, 1(40). Retrieved from http://forumoswiatowe.pl/index.php/czasopismo/article/download/363/231

Inoue, Y. (2006). Open access overview, 437-438. https://doi.org/10.1109/ASPDAC.2006.1594722

Kadek Suhardita. (2011). Efektivitas Penggunaan Teknik Permainan dalam Bimbingan Kelompok untuk Meningkatkan Kepercayaan Diri Siswa. Edisi Khusus, (1), 127-138. Retrieved from http://jurnal.upi.edu/abmas/view/641/efektivitas-penggunaan-teknik-permainan-dalambimbingan-kelompok-untuk-meningkatkan-percaya-diri-siswa(penelitian-quasi-eksperimen-padasekolah-menengah-atas-laboratorium-(percontohan)-upi-bandung-tahun-ajaran-2010

Konseling, K., Behavioral, K., Desensitization, S., Musik, B., Jawa, K., Mereduksi, U., \& Apprehension, C. (2016). Jurnal Bimbingan Konseling, 5(1), 74-81. Retrieved from https://journal.unnes.ac.id/sju/index.php/jubk/article/view/18531

López Mena, L. (1992). Dificultades para la motivación mediante refuerzo positivo en la empresa. Revista de Psicología Del Trabajo Y de Las Organizaciones = Journal of Work and Organizational Psychology, 8(22), 77-88. Retrieved from

http://dialnet.unirioja.es/servlet/articulo?codigo=109466\&info=resumen\&idioma=SPA

Maag, J. W. (2001). Rewarded by Punishment : Reflections on the Disuse of Positive Reinforcement in Schools. Exceptional Children, 67(2), 173-186. https://doi.org/10.1111/j.1937-8327.1995.tb00678.x

Mora, D. M., Salazar, W., \& Valverde, R. (2001). Efectos De La Música-Danza Y Del Refuerzo Positivo En La Conducta De Personas Con Discapacidad Múltiple. Revista de Ciencias Del Ejercicio Y La Salud ® , 1(1), 19-33. https://doi.org/10.15517/pensarmov.v1i1.420

Na, I., Wa, M., Asili, M., \& Ofisi, D. (2008). Taarifa ya Kiikolojia ya Msitu wa Magombera. Retrieved from http://eprints.whiterose.ac.uk/75087/

Pankiewicz, M. (2007). Style Komunikacji a Preferencje Wartości, (Fiske 1999), 39-56. Retrieved from http://sargon.kul.lublin.pl/files/208/3_t-14-9-art.pdf

Papahana, H. E., Ke, I. N. O., Hopuna, A., \& Ka, M. A. (2014). Ke Mau Nei No Na Leo Kupana. Retrieved from http://scholarspace.manoa.hawaii.edu/handle/10125/100351

Penar-zadarko, B., \& Binkowska-bury, M. (2008). N auczyciel jutra - modelowa sylwetka nauczyciela akademickiego studiów zawodowych na kierunku pielęgniarstwo i położnictwo, 66-71. Retrieved from https://journals.viamedica.pl/problemy_pielegniarstwa/article/view/23407

Shapiro, S. J., Bloomsmith, M. A., \& Laule, G. E. (2003). Positive Reinforcement Training as a Technique to Alter Nonhuman Primate Behavior: Quantitative Assessments of Effectiveness. Journal of Applied Animal Welfare Science, 6(3), 175-187. https://doi.org/10.1207/S15327604JAWS0603_03

Siekańska, M. (2004). Psychologiczne uwarunkowania sukcesów zawodo wych, (3). Retrieved from 
http://www.kul.pl/files/714/media/3.47.2004.art.4.pdf..pdf

Siswa, P., Viii, K., Smp, A., Sawan, N., \& Pelajaran, T. (2013). 3 1,2,3. Retrieved from http://ejournal.undiksha.ac.id/index.php/JJBK/article/view/900

Smidt, D. J. T. de. (1975). cultuurtechnische dienst-utrecht. Retrieved from http://library.wur.nl/WebQuery/wurpubs/fulltext/211766

Steptoe, A., Kerry, S., Rink, E., \& Hilton, S. (2001). The impact of behavioral counseling on stage of change in fat intake, physical activity, and cigarette smoking in adults at increased risk of coronary heart disease. American Journal of Public Health, 91(2), 265-269.

https://doi.org/10.2105/AJPH.91.2.265

Sutarjo, I. E., Wmp, D. A., \& Suarni, N. K. (2014). Efektivitas Teori Behavioral Teknik Relaksasi dan Brain Gym Untuk Menurunkan Burnout Belajar Pada Siswa Kelas VIII SMP Laboratorium UNDIKSHA SINGARAJA Tahun Pelajaran 2013/2014. E-Journal Undiksa Jurusan Bimbingan Konseling, 2(1). Retrieved from http://ejournal.undiksha.ac.id/index.php/JJBK/article/view/3740

Tibshirani, B. E. and R. (1986). Institute of Mathematical Statistics is collaborating with JSTOR to digitize, preserve, and extend access to Statistical Science. ${ }^{\circledR}$ www.jstor.org. Statistics, 1, 55-77. Retrieved from http://www.jstor.org/stable/2245500

U.V.Duvel. (n.d.). Agricola_2_1985_8.pdf. Retrieved from http://www.nbri.org.na/sites/default/files/Agricola_2_1985_8.pdf

Vries, dr. B. de. (n.d.). Een eigen huis ..., 401-456. Retrieved from http://pubnpp.eldoc.ub.rug.nl/FILES/root/tijdschrift/CDV/CDV1985/CDV_1985_09.pdf

Warman, D. (2013). Hubungan Percaya Diri Siswa dengan Hasil Belajar Geografi Kelas XI IPS di SMAN 1 Bayang Kabupaten Pesisir Selatan. Retrieved from http://ejournal.unp.ac.id/students/index.php/pgeo/article/view/576

Whitlock, E. P., Orleans, C. T., Pender, N., \& Allan, J. (2002). Evaluating primary care behavioral counseling interventions - An \nevidence-based approach. American Journal of Preventive Medicine, 22(4), 267-284. https://doi.org/10.1016/S0749-3797(02)00415-4

Zegers, L. J., \& Duits-nederlandse, O. (2008). Inhuur private bedrijven, (4). Retrieved from http://www.militairespectator.nl/sites/default/files/bestanden/uitgaven/Militaire Spectator 42008.pdf

Copyrights Holder: Putri Majiatulhibah, I Wayan Tirka, Dewi Arum. MWP 2017

https://doi.org/10.23887/128192017

Open Access Article | CC-BY Creative Commons Attribution 4.0 International License. Word Count:

\section{Conflict of Interest Disclosures:}

The authors declare that they have no significant competing financial, professional or personal interests that might have influenced the performance or presentation of the work described in this manuscript.

First Publication Right: BISMA The Journal of Counseling

\section{@creative}

